\title{
PENGARUH PERBANDINGAN AIR REBUSAN IKAN BANDENG PRESTO DENGAN GULA AREN TERHADAP KARAKTERISTIK SAUS IKAN
}

\author{
Nana Sutisna Achyadi, Yusep Ikrawan, Casianti \\ Program Studi Teknologi Pangan, Fakultas Teknik, Universitas Pasundan, \\ J1. Dr.Setiabudi No 93, Bandung, 40153, Indonesia \\ E-mail : nanasutisnaachyadi@unpas.ac.id
}

\begin{abstract}
Abstrak
Penelitian ini dilakukan untuk mengetahui pengaruh rasio kaldu bandeng presto dengan gula aren terhadap karakteristik kecap ikan. Penelitian ini bertujuan untuk memberikan informasi kepada masyarakat dan industri pangan tentang pemanfaatan dan diversifikasi pangan lokal olahan dengan bahan baku bandeng presto. Stok bandeng presto kaya akan protein, karbohidrat dan lemak sehingga dapat memberikan nilai tambah dan meningkatkan nilai ekonomis dari kaldu bandeng presto dengan gula aren, serta memberikan alternatif pilihan untuk memanfaatkan kaldu bandeng presto yaitu masih dapat diterima secara organoleptik. Penelitian ini menggunakan Rancangan Acak Kelompok (RAK) dengan satu faktor dan enam ulangan. Penelitian ini menggunakan faktor tunggal yaitu rasio kaldu bandeng presto dengan gula aren yang terdiri dari 4 taraf yaitu (2: 3), (1: 1), (3: 2) dan (3: 1). Respon kimiawi pada kecap ikan meliputi kandungan karbohidrat, kandungan protein, kandungan lemak, dan kandungan air. Respon fisik kecap meliputi viskositas dan total padatan terlarut. Uji organoleptik dilakukan berdasarkan tingkat kesukaan panelis dengan metode hedonik meliputi warna, rasa, dan aroma sebagai respon uji Hasil penelitian menunjukkan bahwa perbandingan stok bandeng presto dengan gula aren berpengaruh nyata terhadap karakteristik kecap ikan yang meliputi rasa, aroma, karbohidrat, protein, lemak, air, viskositas, dan total padatan terlarut. Namun, itu tidak terlalu mempengaruhi warnanya.
\end{abstract}

Kata kunci : Kaldu ikan bandeng, gula aren, kecap ikan

\begin{abstract}
This research was conducted to investigate the influence of ratio of pressure-cooked milkfish stock with palm sugar to the characteristics of fish sauce. This research aimed to provide information for the public and food industries for the utilization and diversification of processed local foods with pressure-cooked milkfish stock as primary ingredients. Pressure-cooked milkfish stock is rich in proteins, carbohydrates and fats so it can provide added value and increase the economic value of pressure-cooked milkfish stock with palm sugar, as well as providing an alternative choice to utilize pressure-cooked milkfish stock which is still organoleptically acceptable. This research used a randomized block design (RBD) with one factor and six repetitions. This research used a single factor, which is the ratio of pressure-cooked milkfish stock with palm sugar, that consists of 4 levels, i.e (2: 3), (1: 1), (3:2), and (3: 1). Chemical responses of the fish sauce include the carbohydrate content, protein content, fat content, and water content. Physical responses the of fish sauce include viscosity and total dissolved solid. The organoleptic test was conducted was based on preference level by the panelists with hedonic method, including color, flavor, and aroma as tested responses. The results showed that the ratio of pressure-cooked milkfish stock with palm sugar significantly affected the characteristics of fish sauce, including taste, aroma, carbohydrate, protein, fat, water, viscosity, and total dissolved solids. However, it did not significantly affect the color.
\end{abstract}

Keywords: Pressure-cooked milkfish stock, palm sugar, fish sauce

\section{Pendahuluan}

Ikan bandeng (Chanos chanos) merupakan ikan yang memiliki kandungan protein tinggi sebesar $20 \%$ dan rendah lemak (Muchtadi,2010). Proses perebusan ikan menggunakan alat presto (bertekanan tinggi) adalah suatu proses dengan pemanfaatan suhu dan tekanan yang tinggi sehingga tulang atau duri ikan menjadi lunak. Ikan Bandeng yang diolah melalui proses perebusan menggunakan alat presto (bertekanan tinggi) disebut ikan bandeng presto.

Proses pengolahan ikan bandeng akan memberikan hasil samping berupa limbah, terutama limbah cair yang dihasilkan dari proses pencucian dan perebusan ikan dalam jumlah yang tidak sedikit. Limbah cair biasanya langsung dibuang ke lingkungan yang dapat menyebabkan pencemaran serta menimbulkan bau yang mengganggu estetika lingkungan (Wijatmoko,2004). 
Informasi yang didapat dari pemilik Perusahaan Bunda Rose Bandeng Presto yang berlokasi di Jalan Karasak Utara I/II No.1 RT.02 RW.06 Kelurahan Karasak Kecamatan Astana Anyar Kota Bandung, kapasitas produksi ikan bandeng presto mencapai $24 \mathrm{~kg}$ perhari atau sebanyak 72 ekor ikan bandeng dimana dilakukan tiga kali produksi dalam seminggu yaitu sekitar $72 \mathrm{~kg}$ per minggu atau sebanyak 216 ekor ikan bandeng presto. Dalam satu kali produksi menghasilkan limbah cair perebusan ikan bandeng sebanyak \pm 19 liter.

Limbah cair industri pemindangan ikan berpotensi mencemari lingkungan karena mengandung banyak bahan organik seperti sisa daging, isi perut, protein, lemak, dan karbohidrat (Dislautkan Kab.Pati, 2013).

Sejauh ini limbah cair ikan bandeng presto belum dimanfaatkan secara optimal, padahal jika dimanfaatkan akan menghasilkan produk- produk baru, hal ini dikarenakan adanya kandungan bahan-bahan yang terdapat pada limbah cair pemindangan ikan yang bermanfaat, seperti protein, lemak, garam, dan lain-lain.

Menurut Penelitian Mulyani (2017), limbah cair hasil perebusan ikan bandeng presto di Perusahaan Bunda Bandeng Presto memiliki kandungan gizi antara lain : karbohidrat $12,83 \%$, protein $1,27 \%$, lemak 3,95\% dan cemaran mikroorganisme yaitu Angka Lempeng Total maksimal didapatkan hasil sebesar 5,6 x $101 \mathrm{CFU} / \mathrm{ml}$ (Amalia, 2017)

Limbah cair sisa pemindangan ikan masih mengandung sejumlah zat gizi dan komponen cita rasa yang terlarut selama perebusan ikan, seperti karbohidrat, protein, lemak dan lain lain, limbah tersebut dapat dimanfaatkan kembali untuk diolah sebagai bahan baku seperti saus ikan. (Astawan,2004)

Aren (Arenga pinnata [Wurmb] merr.) merupakan salah satu jenis palem yang tumbuh di bumi Nusantara, yang dikenal oleh sebagian masyarakat sejak zaman penjajahan Belanda lantaran palem menghasilkan nira sebagai bahan baku pembuatan gula aren dan minuman beralkohol yang cukup populer di masa itu. Dari aspek kegunaannya, pohon aren termasuk multifungsi lantaran seluruh bagian tanamannya dapat dimanfaatkan oleh masyarakat (Widyawati,2011).

Areal dan produksi gula aren yang terbesar terdapat pada provinsi: Jawa Barat 13.135 ha dengan produksi 6.686 ton gula/tahun. Perkiraan data produksi nira aren di Jawa Barat dengan luasan lahan 13.135 ha adalah 66.860.000 liter/tahun.Salah satu kabupaten sentra gula aren di Jawa Barat adalah Kabupaten Subang.

Berdasarkan data dari Badan Pusat Statistik tahun 2010 menyebutkan bahwa produksi gula aren yang dihasilkan oleh industri rumah tangga adalah sebesar 2,1 juta ton per tahun (Badan Pusat Statistik (2010) dalam Nanang).

Penggunaan gula aren dalam proses pembuatan saus cuko dapat berperan sebagai bahan pemanis alami, gula aren juga memiliki kelebihan lain yaitu selain bertindak sebagai bahan pemanis alami, namun gula aren juga dapat bertindak sebagai pewarna dan memiliki aroma yang khas.

Saus adalah cairan kental (pasta) yang terbuat dari bubur buah berwarna menarik (biasanya merah), mempunyai aroma dan rasa yang merangsang. Walaupun mengandung air dalam jumlah besar, saus mempunyai daya simpan panjang karena mengandung asam, gula, garam dan seringkali diberi pengawet. Tekstur saus yang kental merupakan ciri dari saus yang ada dipasaran.Biasanya digunakan pengental yang sengaja ditambahkan, biasanya jenis pengental yang digunakan berbahan dasar pati (Tarwiyah, 2001).

Saus ikan didefinisikan sebagai saus kental bewarna agak kehitaman yang memiliki rasa gurih dan asin yang digunakan sebagai penyedap makanan yang memiliki rasa, aroma, tekstur, dan warna yang khas (Citra , 2015).

Pemanfaatan air rebusan ikan bandeng presto yang ditambahkan dapat berpengaruh terhadap flavor saus ikan karena terdapat kadar garam $(\mathrm{NaCl})$ yang sebesar $1,05 \%$ (Gustina, 2016). Penambahan air rebusan ikan bandeng presto yang berlebih akan menyebabkan rasa saus ikan menjadi terlalu asin.

Kualitas saus yang baik dinilai dari flavor, kekentalan, dan warna yang menarik. Berdasarkan kekentalannya, viskositas merupakan komponen fisik yang terpenting dalam produk Saus (Sharoba et al, 2005).

Fungsi gula dalam pembuatan saus ikan adalah untuk memberi rasa manis dan kelembutan yang mempunyai daya larut tinggi. Mempunyai kemampuan untuk menurunkan aktivitas air (aw) dan mengikat air. Air merupakan komponen penting dalam bahan makanan karena air dapat mempengaruhi penampakan, tekstur, daya tahan bahan serta cita rasa makanan. Gula yang ditambah dalam bahan pangan dengan konsentrasi yang sangat tinggi (minimal $40 \%$ padatan terlarut) akan mengakibatkan jumlah air bebas yang ada dalam bahan pangan tersebut menjadi tidak tersedia bagi pertumbuhan mikroorganisme (Buckle dkk., 1987 dalam Sara, 2011).

Menurut Alhanannasir Syukri 2014, konsentrasi gula semut berpengaruh terhadap kualitas saus cuko pempek.Berdasarkan penelitian tersebut diketahui kualitas saus cuko pempek yang baik dengan penambahan gula semut sebanyak 60\%.Gula aren memiliki kandungan sukrosa yang cukup tinggi, sehingga perbandingan antara air rebusan ikan bandeng presto dan gula aren harus ditentukan guna menghasilkan saus ikan yang dapat diterima secara organoleptik oleh masyarakat.

\section{Bahan dan Metode Penelitian}

Bahan baku utama yang digunakan dalam penelitian ini adalah air rebusan ikan bandeng presto yang diperoleh dari perusahaan "Bunda Rose Bandeng Presto", sedangkan bahan baku gula aren diperoleh dari pasar tradisional. Bahan baku penunjang dalam penelitian ini adalah tapioka, garam.

Bahan-bahan yang digunakan untuk analisis kimia adalah aquadest, larutan Luff Schoorl, KI padat, Larutan 
baku Na2S2O3, amilum, HCL 9,5 N, HCL 0,1 N. NaOH $30 \%$, garam kjeldahl, larutan $\mathrm{H} 2 \mathrm{SO} 4$, batu didih, granul $\mathrm{Zn}$, larutan baku $\mathrm{NaOH}$, phenolptalein, N-Heksan, alkohol, dan larutan buffer.

Alat-alat yang digunakan pada pembuatan saus ikan dengan penambahan konsentrasi tepung tapioca adalah timbangan, pisau stainlees steel, talenan, sendok, panci stainlees steel, pengaduk, kompor, botol jam beserta tutupnya.

Alat-alat yang digunakan pada penelitian ini adalah labu erlenmeyer $100 \mathrm{~mL}$, labu ukur $100 \mathrm{~mL}$, batang pengaduk, pipet volumetrik, pipet tetes, neraca digital, alat refluks, kertas saring, gelas kimia, corong, labu ukur, labu kjeldahl, kompor, adaptor, alat destilasi, statif, klem, buret, plastik sampel, benang kasur, sokhlet, penangas, labu dasar bulat, oven, eksikator, $\mathrm{pH}$ meter, cawan penguapan, penjepit cawan, viscometer, dan refraktometer.

Metode penelitian yang dilakukan terdiri dari penelitian pendahuluan dan penelitian utama. Rancangan perlakuan pada penelitian pendahuluan terdiri dari Pengujian bahan baku saus ikan yaitu air rebusan ikan bandeng presto dengan menentukan kadar karbohidrat, kadar protein dan kadar lemak, kemudian dilakukan penentuan konsentrasi tapioka pada saus ikan, yaitu: 1\%; $1.5 \%$; dan $2 \%$. Produk saus ikan yang diperoleh akan diuji secara fisik untuk mengetahui tingkat kekentalan terhadap saus ikan menggunakan viscometer.

Saus ikan dengan konsentrasi tapioka terbaik akan digunakan untuk penelitian utama. Penelitian ini akan menentukan perbandingan air rebusan ikan bandeng presto dan gula aren yang tepat untuk menghasilkan produk saus ikan yang dapat diterima secara karakteristik.

Rancang perlakuan terdiri dari satu faktor yaitu perbandingan air rebusan ikan bandeng presto dengan gula aren yang terdiri dari empat taraf perbandingan air rebusan ikan bandeng presto dan gula aren yaitu : $\mathrm{p} 1=$ $(2: 3) ; \mathrm{p} 2=(1: 1) ; \mathrm{p} 3=(3: 2) ; \mathrm{p} 4=(3: 1)$. Rancangan percobaan yang dilakukan pada penelitian ini adalah Rancangan Acak Kelompok (RAK) dengan pola satu (1) faktor dengan 6 kali pengulangan sehingga diperoleh 24 perlakuan.

Tahapan pembuatan saus ikan yang dilakukan pada penelitian ini adalah sebagai berikut.

1. Pembuatan air rebusan ikan bandeng presto

Ikan bandeng presto dipilih berdasarkan ukuran ikan, kemudian dilakukan Proses trimming dapat dilakukan dengan cara dibelah dan dibuang isi perutnya (Jeroan).Ikan yang sudah disiangi atau dibelah, langsung dicuci dengan air bersih yang mengalir sampai kotoran yang menempel pada perut tubuh ikan hilang. Tambahkan bumbu-bumbu yang digunakan seperti Bawang merah 1,14\% ; bawah putih $1,14 \%$; jahe $1,14 \%$ ; garam 2,27\% ; MSG $0.11 \%$; serai $0,02 \%$; dau salam $0,009 \%$; laos $0,68 \%$; air bersih $90,9 \%$ kemudian lakukan proses pemasakan dilakukan dengan menggunakan alat pressure cooker dengan suhu $121^{\circ} \mathrm{C}$, $\mathrm{P}=1 \mathrm{~atm} \mathrm{t}=4 \mathrm{jam}$. Setelah pemasakan ikan di diamkan di dalam panci presto hingga suhu pada panci presto turun, Setelah pendinginan, ikan diangkat satu persatu dengan hati-hati kemudian di letakkan berjajar di atas tray. Kemudian, tampung air rebusan ikan bandeng kedalam wadah.

2. Penyaringan

Proses pembuatan saus ikan diawali dengan penyaringan air rebusan ikan bandeng presto bertujuan untuk memisahkan kotoran dari sisa proses pemasakan ikan bandeng presto seperti serai, daun salam dan laos .

3. Pencacahan gula

Gula aren yang digunakan berbentuk tabung dengan diameter kurang lebih $10 \mathrm{~cm}$, sehingga untuk mempercepat kelarutan gula dalam pembuatan permen perlu dilakukan pengecilan ukuran gula yaitu dengan cara dicacah.

4. Pencampuran I

Air rebusan ikan bandeng presto dan gula aren kemudian dicampurkan dengan perbandingan sesuai dengan perlakuan.

5. Pemasakan

Tambahkan garam $6 \%$ dan tambahkan larutan tapioca yang terpilih, kemudian pemasakkan dilakukan pada suhu $850 \mathrm{C}$ selama 25 menit sambil diaduk perlahanlahan dengan menggunakan sendok pengaduk.

6. Kekentalan

Periksa kekentalan saus ikan sampai kekentalan yang diinginkan.

Respon yang akan dilakukan pada penelitian ini adalah respon kimia, respon fisika, dan respon organoleptik. Respon Kimia yang dilakukan terhadap produk saus ikan adalah analisis kadar protein dengan menggunakan metode Kjedahl (AOAC, 2005), analisis kadar karbohidrat dengan menggunakan metode luff schoorl (AOAC, 2005), kadar lemak dengan menggunakan metode Soxhlet (AOAC, 2005), dan kadar air dengan metode gravimetri (AOAC, 2005). Respon fisika yang dilakukan adalah analisis kekentalan dengan alat viscometer (Wahyudi, 2011), dan total padatan dengan alat refraktometer (Sudarmadji, 2003). Pengujian organoleptik digunakan pada produk akhir saus ikan adalah uji Hedonik yang merupakan penilaian seseorang akan sifat atau kualitas bahan yang menyebabkan orang menyenanginya (Soekarto 1985). Respon yang diuji meliputi warna, rasa, dan aroma (uji hedonik) pada saus ikan yang dilakukan oleh 30 panelis semi terlatih.

\section{Hasil dan Pembahasan Hasil Penelitian Pendahuluan}

Penelitian pendahuluan dilakukan untuk mengetahui analisis bahan baku utama yaitu air rebusan ikan bandeng presto berupa kadar karbohidrat, kadar protein, dan kadar lemak. Tujuan dilakukan analisi bahan baku yaitu untuk mengetahui adanya pengurangan atau penambahan pada bahan baku sampai menjadi produk akhir. 
Tabel 1. Hasil Uji Pendahuluan Analisis kimia Air rebusan ikan bandeng

\begin{tabular}{cccc}
\hline Sampel & $\begin{array}{c}\text { Kadar } \\
\text { Karbohidrat }\end{array}$ & $\begin{array}{c}\text { Kadar } \\
\text { Protein }\end{array}$ & $\begin{array}{c}\text { Kadar } \\
\text { Lemak }\end{array}$ \\
\hline $\begin{array}{c}\text { Air rebusan } \\
\text { ikan bandeng } \\
\text { presto }\end{array}$ & $0 \%$ & 9,94 & 0,4005 \\
\hline
\end{tabular}

Hasil analisis kadar gula menunjukkan bahwa air rebusan ikan bandeng presto tersebut memiliki kadar gula sebesar $0 \%$. Air rebusan ikan bandeng presto diperoleh dari hasil pemasakan ikan bandeng duri lunak/ ikan bandeng presto. Menurut (Rose B, 2017) Kandungan gizi ikan bandeng duri lunak/ ikan bandeng presto yaitu kadar karbohidrat $0,21 \%$, kadar protein $54,60 \%$, dan kadar lemak 2,57\%. Tidak adanya karbohidrat pada air rebusan ikan bandeng presto karena karbohidrat dalam ikan tidak terlarut selama proses pemasakan dan pada proses pemasakan tidak menggunakan gula, sehingga kadar karbohidrat yang dihitung adalah kadar gula sebelum inversi.

Karbohidrat adalah sumber energi kalori utama bagi tubuh manusia, karbohidrat dalam tubuh berguna untuk mencegah timbulnya pemecahan protein tubuh yang berlebihan, kehilangan mineral dan berguna untuk membantu metabolism lemak dan protein, karbohidrat juga mempunyai peranan penting dalam menentukan karakteristik bahan makanan seperti rasa, warna, tekstur, dan lain-lain (Winarno,1997)

Analisis bahan baku air rebusan ikan bandeng presto dilakukan untuk mengetahui kadar protein, analisis ini dilakukan dengan metode kjeldahl. Hasil analisis kadar protein menunjukkan bahwa air rebusan ikan bandeng presto tersebut memiliki kadar protein sebesar $9,94 \%$.

Jumlah kadar protein tersebut cukup tinggi jika dibandingkan dengan hasil yang dilaporkan sebesar 1,27\% (Mulyani,2016)

Protein merupakan suatu zat yang penting bagi tubuh karena berfungsi sebagai zat pembangun dan pengatur. Protein adalah sumber-sumber asam amino yang mengandung unsur-unsur $\mathrm{C}, \mathrm{H}, \mathrm{O}$, dan $\mathrm{N}$ yang tidak dimiliki oleh lemak atau karbohidrat. Fungsi utama protein adalah untuk membentuk jaringan baru dan mempertahankan jaringan yang telah ada, dan sebagai bahan bakar apabila keperluan energi tubuh tidak terpenuhi oleh karbohidrat dan lemak (Winarno, 1997).

Analisis bahan baku air rebusan ikan bandeng presto dilakukan untuk mengetahui kadar lemak, analisis ini dilakukan dengan metode sohxlet. Hasil analisis kadar lemak menunjukkan bahwa air rebusan ikan bandeng presto tersebut memiliki kadar lemak sebesar $0,4005 \%$.

Terjadinya penurunan kadar lemak setelah pemasakan disebabkan karena sifat lemak yang tidak tahan panas, selama proses pemasakan lemak mencair bahkan menguap menjadi komponen lain seperti flavor.
Tabel 2. Hasil uji pendahuluan viskositas

\begin{tabular}{cccc}
\hline Air rebusan & \multicolumn{3}{c}{ Nilai rata-rata viskositas(cps) } \\
\cline { 2 - 4 } ikan bandeng $\begin{array}{c}\text { Tando } \\
\text { presto } \\
\text { gula aren }\end{array}$ & Tapioka 1\% & $\begin{array}{c}\text { Tapioka } \\
1,5 \%\end{array}$ & Tapioka 2\% \\
\hline $2: 3(\mathrm{p} 1)$ & 91,31 & 1159,96 & 1493,05 \\
\hline $1: 1(\mathrm{p} 2)$ & 86,58 & 285,56 & 377,27 \\
\hline $3: 2(\mathrm{p} 3)$ & 35,19 & 172,72 & 190,81 \\
\hline $3: 1(\mathrm{p} 4)$ & 11,34 & 114,05 & 152,481 \\
\hline
\end{tabular}

Nilai rata-rata viskositas pada tabel 10 menunjukan perlakuan perbandingan air rebusan ikan bandeng presto dengan gula aren dengan menggunakan tapioka $1 \%$ pada p1 (2:3) mendapatkan nilai rata-rata tertinggi $91,31 \mathrm{cps}$, sedangkan p4 (3:1) mendapatkan nilai rata-rata terendah $11,34 \mathrm{cps}$, sedangkan pada p2(1:1) diperoleh nilai sebasar 86,58 cps, p3(3:2) 35,19 cps.

Perlakuan perbandingan air rebusan ikan bandeng presto dengan gula aren dengan menggunakan tapioka $1,5 \%$ pada $\mathrm{p} 1$ (2:3) mendapatkan nilai rata-rata tertinggi 1159,96 cps, sedangkan p4 (3:1) mendapatkan nilai ratarata terendah 114,05 cps, sedangkan pada $\mathrm{p} 2(1: 1)$ diperoleh nilai sebasar 285,56 cps, p3(3:2) 172,72 cps. Perlakuan perbandingan air rebusan ikan bandeng presto dengan gula aren dengan menggunakan tapioka $2 \%$ pada p1 (2:3) mendapatkan nilai rata-rata tertinggi $1493,05 \mathrm{cps}$, sedangkan p4 (3:1) mendapatkan nilai ratarata terendah $152,481 \mathrm{cps}$, sedangkan pada $\mathrm{p} 2(1: 1)$ diperoleh nilai sebasar 377,27 cps, p3(3:2) 190,81cps.

Berdasarkan hasil nilai viskositas dari tabel 2, menunjukan bahwa perbandingan air rebusan ikan bandeng presto dengan gula aren mendapatkan nilai viskositas yang berbeda-beda. salah satu faktor yang sangat mempengaruhi viskositas adalah konsentrasi tapioka yang dipakai. Semakin tinggi konsentrasi tapioka yang digunakan semakin tinggi pula nilai viskositas.

Menurut Imam (2016), nilai viskositas tertinggi pada pembuatan saus cuko adalah 400,53 cps, sehingga konsentari tapioka yang terpilih adalah $1 \%$ karena semua nilai viskositas pada semua perlakuan masuk kedalam syarat nilai viskositas untuk saus ikan.

\section{Hasil Penelitian Utama}

\section{Kadar Karbohirat}

Berdasarkan hasil analisis, perlakuan perbandingan air rebusan ikan bandeng presto dengan gula aren memberikan pengaruh nyata terhadap kadar gula total saus ikan. Hasil uji lanjut duncan kadar gula total dapat dilihat pada Tabel 3 .

Tabel 3. Kadar gula total saus ikan bandeng

Air rebusan ikan bandeng Gula total Taraf nyata 5\% presto : gula aren

(\%)

\begin{tabular}{lll}
\hline $2: 3(\mathrm{p} 1)$ & 50,59 & $\mathrm{~d}$ \\
\hline $1: 1(\mathrm{p} 2)$ & 42,53 & $\mathrm{c}$ \\
\hline $3: 2(\mathrm{p} 3)$ & 34,33 & $\mathrm{~b}$ \\
\hline $3: 1(\mathrm{p} 4)$ & 22,80 & $\mathrm{a}$ \\
\hline
\end{tabular}


Keterangan : Nilai rata-rata yang diikuti oleh huruf yang berbeda menunjukan perbedaan yang nyata menurut Uji Duncan pada taraf $5 \%, \pm$ menunjukan standar deviasi.

Kandungan gula total tertinggi terdapat pada perlakuan $\mathrm{p} 1$ dengan perbandingan air rebusan ikan bandeng dengan gula aren ( $2: 3)$ dengan nilai gula total sebesar 50,599\%, sedangkan pada perlakuan p2(1:1) diperoleh nilai sebesar 42,53\%, p3 (3:2) 34,33\%, dan p4 (3:1) memperoleh hasil gula total terendah dengan nilai $22,80 \%$.

Hasil penelitian menunjukan nilai gula total yang berbeda-beda. Hal ini dikarenakan adanya perbedaan air rebusan ikan bandeng presto dengan gula aren sehingga tiap- tiap perlakuan memiliki formulasi yang berbeda pula. Perlakuan p1 dengan perbandingan air rebusan ikan bandeng presto dengan gula aren (2:3) menunjukan nilai gula total tertinggi disebabkan jumlah gula aren yang digunakan paling banyak dibanding formulasi perlakuan lainnya.

Gula reduksi merupakan golongan gula (karbohidrat) yang dapat mereduksi senyawa-senyawa penerima elektron, contohnya adalah glukosa dan fruktosa. Ujung dari suatu gula reduksi adalah ujung yang mengandung gugus aldehid atau keton (Septyani, 2015).

Menurut (Sapari, dalam Lempang, 2012) gula aren mengandung glukosa cukup tinggi. Gula aren juga mengandung sukrosa yang cukup tinggi dibandingkan dengan gula tebu dan gula bit dimana pada $\mathrm{pH}$ rendah (suasana asam) sukrosa dapat tereduksi menjadi glukosa dan fruktosa yang disebut gula reduksi karena adanya gugus $\mathrm{OH}$ bebas yang reaktif. Hal ini sesuai dengan pendapat (Desrosier, 1988) bahwa sukrosa bersifat non pereduksi karena tidak mempunyai gugus $\mathrm{OH}$ bebas yang reaktif, tetapi selama pemasakan dengan adanya asam, sukrosa akan terhidrolisis menjadi gula invert yaitu fruktosa dan glukosa yang merupakan gula reduksi.

Pemanasan larutan sukrosa dengan perbandingan yang berbeda-beda dalam kondisi asam akan menyebabkan proses hidrolisis yang menghasilkan gula reduksi yang berbeda-beda pula. Dalam proses pemanasan sukrosa ini akan terjadi pemecahan sukrosa menjadi glukosa dan fruktosa akibat pengaruh asam dan panas yang akan meningkatkan kelarutan gula. Sesuai dengan pendapat (winarno, 1992) bahwa sukrosa yang dilarutkan dalam air akan terurai sebagian menjadi glukosa dan fruktosa yang disebut sebagai gula invert. Inversi sukrosa ini terjadi dalam suasana asam serta meningkatkan kelarutan.

\section{Kadar Protein}

Hasil uji lanjut duncan kadar protein dapat dilihat pada Tabel 4.

Berdasarkan hasil analisis kimia terhadap kadar protein menunjukan bahwa kandungan protein tertinggi terdapat pada perlakuan p4 dengan perbandingan air rebusan ikan bandeng presto dengan gula aren ( $3: 1)$ dengan nilai protein sebesar $5,77 \%$, sedangkan pada perlakuan p3(3:2) diperoleh nilai sebesar 5,24\%, p2 (1:1)
$4,85 \%$, dan p1 (2:3) memperoleh hasil protein terendah dengan nilai $4,6 \%$.

Tabel 4. Kadar protein saus ikan bandeng

\begin{tabular}{|c|c|c|}
\hline $\begin{array}{c}\text { Air rebusan } \\
\text { ikan } \\
\text { bandeng } \\
\text { presto : gula } \\
\text { aren }\end{array}$ & $\begin{array}{c}\text { Protein } \\
(\%)\end{array}$ & $\begin{array}{c}\text { Taraf nyata } \\
5 \%\end{array}$ \\
\hline $2: 3(\mathrm{p} 1)$ & 4,6 & $\mathrm{a}$ \\
\hline $1: 1(\mathrm{p} 2)$ & 4,85 & $\mathrm{~b}$ \\
\hline $3: 2(\mathrm{p} 3)$ & 5,24 & $\mathrm{c}$ \\
\hline $3: 1(\mathrm{p} 4)$ & 5,77 & $\mathrm{~d}$ \\
\hline
\end{tabular}

Hasil penelitian menunjukan nilai protein yang berbeda-beda. Hal ini dikarenakan adanya perbedaan air rebusan ikan bandeng presto dengan gula aren sehingga tiap- tiap perlakuan memiliki formulasi yang berbeda pula. Perlakuan $\mathrm{p} 4$ dengan perbandingan air rebusan ikan bandeng presto dengan gula aren (3:1) menunjukan nilai protein tertinggi disebabkan jumlah air rebusan ikan bandeng presto yang digunakan paling banyak dibanding formulasi perlakuan lainnya.

Kandungan gizi air rebusan ikan bandeng memiliki kadar protein 9,94 \% sehingga semakin tinggi penambahan air rebusan ikan bandeng presto pada pembuatan saus ikan maka kadar protein saus ikan juga semakin tinggi karena banyak protein yang terlarut.

3. Kadar Lemak

Hasil uji lanjut duncan kadar lemak dapat dilihat pada Tabel 5.

Tabel 5. Kadar lemak saus ikan Bandeng

Air rebusan ikan

bandeng presto : $\quad$ Lemak (\%) Taraf nyata 5\% gula aren

\begin{tabular}{lll}
\hline $2: 3(\mathrm{p} 1)$ & 1,94 & $\mathrm{a}$ \\
\hline $1: 1(\mathrm{p} 2)$ & 2,12 & $\mathrm{~b}$ \\
\hline $3: 2(\mathrm{p} 3)$ & 2,46 & $\mathrm{c}$ \\
\hline $3: 1(\mathrm{p} 4)$ & 2,57 & $\mathrm{~d}$
\end{tabular}

Ketarangan : Nilai rata-rata yang diikuti oleh huruf yang berbeda menunjukan perbedaan yang nyata menurut Uji Duncan pada taraf $5 \%, \pm$ menunjukan standar deviasi.

Berdasarkan hasil analisa kimia terhadap kadar lemak menunjukan bahwa kandungan lemak tertinggi terdapat pada perlakuan $\mathrm{p} 4$ dengan perbandingan air rebusan ikan bandeng presto dengan gula aren ( $3: 1)$ dengan nilai protein sebesar $2,57 \%$, sedangkan pada perlakuan p3(3:2)diperoleh nilai sebesar 2,46\%, p2 (1:1) $2,12 \%$, dan p1 (2:3) memperoleh hasil kadar lemak terendah dengan nilai $1,94 \%$.

Hasil penelitian menunjukkan nilai lemak yang berbeda-beda. Hal ini dikarenakan adanya perbedaan air rebusan ikan bandeng presto dengan gula aren sehingga tiap- tiap perlakuan memiliki formulasi yang berbeda pula. Perlakuan p4 dengan perbandingan air rebusan ikan bandeng presto dengan gula aren (3:1) menunjukkan nilai 
lemak tertinggi disebabkan jumlah air rebusan ikan bandeng presto yang digunakan paling banyak dibanding formulasi perlakuan lainnya.

Kandungan gizi air rebusan ikan bandeng memiliki kadar lemak 0,4005\% sehingga semakin tinggi penambahan air rebusan ikan bandeng presto pada pembuatan saus ikan maka kadar lemak saus ikan . Hal ini dikarenakan, Air rebusan ikan bandeng itu sendiri memiliki kandungan lemak yang cukup tinggi, sehingga dapat mempengaruhi total kandungan lemak yang terdapat pada produk.

\section{Kadar Air} Tabel 6.

Hasil uji lanjut duncan kadar air dapat dilihat pada

Tabel 6. Kadar Air Saus Ikan Bandeng

\begin{tabular}{ccc}
\hline $\begin{array}{c}\text { Air rebusan ikan } \\
\text { bandeng presto : gula } \\
\text { aren }\end{array}$ & Air (\%) & $\begin{array}{c}\text { Taraf nyata } \\
5 \%\end{array}$ \\
\hline $2: 3(\mathrm{p} 1)$ & 42,87 & $\mathrm{a}$ \\
\hline $1: 1(\mathrm{p} 2)$ & 50,50 & $\mathrm{~b}$ \\
\hline $3: 2(\mathrm{p} 3)$ & 57,97 & $\mathrm{c}$ \\
\hline $3: 1(\mathrm{p} 4)$ & 68,86 & $\mathrm{~d}$ \\
\hline
\end{tabular}

Ketarangan : Nilai rata-rata yang diikuti oleh huruf yang berbeda menunjukan perbedaan yang nyata menurut Uji Duncan pada taraf $5 \%$, menunjukan besaran standar deviasi.

Berdasarkan hasil analisa kimia terhadap kadar air menunjukan bahwa kandungan air tertinggi terdapat pada perlakuan p4 dengan perbandingan air rebusan ikan bandeng presto dengan gula aren (3:1) dengan nilai air sebesar $68,86 \%$, sedangkan pada perlakuan p3(3:2) diperoleh nilai sebesar 57,97\%, p2 (1:1) 50,50\%, dan p1 (2:3) memperoleh hasil kadar air terendah dengan nilai $42,87 \%$.

Hasil penelitian menunjukan nilai lemak yang berbeda-beda. Hal ini dikarenakan adanya perbedaan air rebusan ikan bandeng presto dengan gula aren sehingga tiap- tiap perlakuan memiliki formulasi yang berbeda pula. Perlakuan p4 dengan perbandingan air rebusan ikan bandeng presto dengan gula aren (3:1) menunjukan nilai air tertinggi disebabkan jumlah air rebusan ikan bandeng presto yang digunakan paling banyak dibanding formulasi perlakuan lainnya.

Air merupakan komponen penting dalam bahan makanan, pada umumnya kadar air pada bahan pangan setelah mengalami proses pemasakan akan berkurang. Hal ini dikarenakan pemasakan merupakan suatu proses pengolahan yang dapat menurunkan kadar air bahan pangan, dan selama pemasakan air banyak yang menguap.

5. Total Padatan Terlarut

Hasil uji lanjut duncan kadar gula total dapat dilihat pada Tabel 7.

Berdasarkan hasil analisa total padatan terlarut menunjukan bahwa kandungan kadar brix tertinggi terdapat pada perlakuan p1 dengan perbandingan air rebusan ikan bandeng presto dengan gula aren (2:3) dengan kadar brix sebesar 57,17\%, sedangkan pada perlakuan p2(1:1) diperoleh nilai sebesar 49,37\%, p3
(3:2) 42,30\%, dan p4 (3:1) memperoleh hasil kadar brix terendah dengan nilai $31,30 \%$.

Tabel 7. Kadar total padatan terlarut saus ikan.

Air rebusan ikan

bandeng presto : gula Brix $(\%) \quad$ Taraf nyata 5\% aren

\begin{tabular}{lll}
\hline $2: 3(\mathrm{p} 1)$ & 57,17 & $\mathrm{a}$ \\
\hline $1: 1(\mathrm{p} 2)$ & 49,37 & $\mathrm{~b}$ \\
\hline $3: 2(\mathrm{p} 3)$ & 42,30 & $\mathrm{c}$ \\
\hline $3: 1(\mathrm{p} 4)$ & 31,30 & $\mathrm{~d}$
\end{tabular}

Ketarangan : Nilai rata-rata yang diikuti oleh huruf yang berbeda menunjukan perbedaan yang nyata menurut Uji Duncan pada taraf $5 \%, \pm$ menunjukan besaran standar deviasi.

Hasil penelitian menunjukan kadar brix yang berbeda-beda. Hal ini dikarenakan adanya perbedaan air rebusan ikan bandeng presto dengan gula aren sehingga tiap- tiap perlakuan memiliki formulasi yang berbeda pula. Perlakuan p1 dengan perbandingan air rebusan ikan bandeng presto dengan gula aren $(2: 3)$ menunjukan nilai kadar brix tertinggi disebabkan jumlah gula aren yang digunakan paling banyak dibanding formulasi perlakuan lainnya.

Nilai total padatan terlarut diukur menggunakan refractometer. Nilai yang terukur dinyatakan dengan ${ }^{\circ}$ Brix, yang merupakan skala hydrometer yang menunjukan persen berat gula yang terdapat didalam larutan. Nilai total padatan terlarut dari saus ikan yang menunjukan nilai paling rendah karena kadar sukrosa yang merupakan komponen gula aren sudah mengalami penurunan akibat terjadinya inversi menjadi monosakarida penyusunnya (Imanda, 2007).

6. Viskositas

Hasil uji lanjut duncan kadar gula total dapat dilihat pada Tabel 8.

Tabel 8. Kadar viskositas saus ikan

Air rebusan ikan Viskositas(cps) Taraf nyata 5\% bandeng presto :gula

aren

\begin{tabular}{ccc}
\hline $2: 3(\mathrm{p} 1)$ & 91,12 & $\mathrm{~d}$ \\
\hline $1: 1(\mathrm{p} 2)$ & 86,5 & $\mathrm{c}$ \\
\hline $3: 2(\mathrm{p} 3)$ & 35,63 & $\mathrm{~b}$ \\
\hline $3: 1(\mathrm{p} 4)$ & 7,71 & $\mathrm{a}$ \\
\hline
\end{tabular}

Ketarangan : Nilai rata-rata yang diikuti oleh huruf yang berbeda menunjukan perbedaan yang nyata menurut Uji Duncan pada taraf 5 $\%, \pm$ menunjukan besaran standar deviasi.

Berdasarkan hasil analisis viskositas menunjukan bahwa nilai viskositas tertinggi terdapat pada perlakuan p1 dengan perbandingan air rebusan ikan bandeng presto dengan gula aren (2:3) dengan nilai viskositas sebesar 91,12 cps, sedangkan pada perlakuan p2(1:1) diperoleh nilai sebesar 86,50 cps, p3 (3:2) 35,63 cps, dan p4 (3:1) memperoleh hasil nilai viskositas terendah dengan nilai $7,71 \mathrm{cps}$. 
Hasil penelitian menunjukan nilai viskositas yang berbeda-beda. Hal ini dikarenakan adanya perbedaan air rebusan ikan bandeng presto dengan gula aren sehingga tiap- tiap perlakuan memiliki formulasi yang berbeda pula. Perlakuan $\mathrm{p} 1$ dengan perbandingan air rebusan ikan bandeng presto dengan gula aren (2:3) menunjukan nilai viskositas tertinggi disebabkan jumlah gula aren yang digunakan paling banyak dibanding formulasi perlakuan lainnya.

Penambahan pati berfungsi sebagai bahan pengikat pada saus ikan berguna untuk memperbaiki tekstur, meningkatkan daya ikat air, dan menurunkan penyusutan akibat pemasakan. Menurut Winarno (2002), peningkatan viskositas dipengaruhi dengan adanya penambahan gula dan konsentrasi gula yang ditambahkan. Semakin banyak komponen gula yang larut maka zat organik yang terlarutkan juga semakin banyak, sehingga jumlah total padatan terlarut menjadi semakin tinggi. Dengan semakin tinggi jumlah total padatan terlarut maka nilai viskositasnya juga semakin tinggi.

7. Uji Organoleptik

a. Rasa

Rasa berbeda dengan bau dan lebih banyak melibatkan panca indera lidah. (Winarno, 1992). Rasa merupakan respon lidah terhadap rangsangan yang diberikan oleh suatu makanan yang merupakan salah satu factor penting yang mempengaruhi tingkat penerimaan panelis atau konsumen terhadap suatu produk makanan. Walaupun memiliki warna dan tekstur yang baik, suatu produk makanan tidak akan diterima oleh panelis atau konsumen bila rasanya tidak enak (Bait, 2012)

Hasil Analisis Variansi (ANAVA) menunjukkan bahwa perlakuan perbandingan air rebusan ikan bandeng presto dengan gula aren memberikan pengaruh nyata terhadap rasa saus ikan. Hasil uji lanjut Duncan dapat dilihat pada Tabel 9 .

Tabel 9. Hasil Uji Organoleptik Rasa Saus Ikan

Air rebusan ikan

bandeng presto : gula

Penilaian Rasa

\begin{tabular}{cc} 
aren & \\
\hline $2: 3(\mathrm{p} 1)$ & $4,00 \mathrm{c}$ \\
\hline $1: 1(\mathrm{p} 2)$ & $3,64 \mathrm{~b}$ \\
\hline $3: 2(\mathrm{p} 3)$ & $3,70 \mathrm{~b}$ \\
\hline $3: 1(\mathrm{p} 4)$ & $3,51 \mathrm{a}$
\end{tabular}

$\overline{\text { Ketarangan : Nilai rata-rata yang diikuti oleh huruf yang berbeda }}$ menunjukan perbedaan yang nyata menurut Uji Duncan pada taraf $5 \%$.

Perbandingan perbandingan air rebusan ikan bandeng presto dengan gula aren p1 (2:3) mendapatkan rata-rata tertinggi yaitu 4,00. Perlakuan p4 (3:1) mendapatkan nilai rata-rata rasa terendah yaitu 3,51 . Sedangkan p2 (1:1) dan p3 (3:2) berturut-turut mendapatkan nilai rata-rata 3,64 dan 3,70.

Perbedaan tingkat kesukaan panelis terhadap rasa dari saus ikan disebabkan oleh adanya perbandingan air rebusan ikan bandeng presto dengan gula aren. air rebusan ikan bandeng presto mengandung banyak garam
1,05\% (Gustina, 2016), sehingga semakin banyak penambahan air rebusan ikan bandeng presto maka akan menyebabkan rasa saus ikan menjadi terlalu asin. Sebaliknya jika perbandingan gula yang ditambahkan semakin banyak maka rasa dari saus ikan akan semakin manis. Peningkatan rasa manis ini disebabkan karena semakin tinggi konsentrasi gula aren (Buckle, dkk., 2009).

b. Aroma

Aroma merupakan salah satu faktor penting dalam menunjukkan tingkat penerimaan konsumen terhadap suatu bahan pangan. Karena aroma menentukan kelezatan bahan makanan. (Rampengan dkk,1985) Pengujian terhadap aroma dianggap penting karena dapat dengan cepat memberikan penilaian terhadap suatu produk diterima atau tidaknya oleh konsumen (Winarno, 1992).

Hasil Analisis Variansi (ANAVA) menunjukkan bahwa perlakuan perbandingan air rebusan ikan bandeng presto dengan gula aren memberikan pengaruh nyata terhadap aroma Saus ikan. Hasil uji lanjut duncan dapat dilihat pada Tabel 10.

Tabel 10. Hasil Uji organoleptik Aroma Saus ikan

Air rebusan ikan

bandeng presto :gula

Aroma aren

\begin{tabular}{cc}
\hline $2: 3(\mathrm{p} 1)$ & $3,83 \mathrm{~b}$ \\
\hline $1: 1(\mathrm{p} 2)$ & $3,54 \mathrm{a}$ \\
\hline $3: 2(\mathrm{p} 3)$ & $3,85 \mathrm{~b}$ \\
\hline $3: 1(\mathrm{p} 4)$ & $4,26 \mathrm{c}$ \\
\hline
\end{tabular}

Ketarangan : Nilai rata-rata yang diikuti oleh huruf yang berbeda menunjukan perbedaan yang nyata menurut Uji Duncan pada taraf $5 \%$.

Perbandingan perbandingan air rebusan ikan bandeng presto dengan gula aren p4 (3:1) mendapatkan rata-rata tertinggi yaitu 4,26. Perlakuan p2 (1:1) mendapatkan nilai rata-rata rasa terendah yaitu 3,54. Sedangkan p1 (2:3) dan p3 (3:2) berturut-turut mendapatkan nilai rata-rata 3,83 dan 3,85.

Secara kimiawi sulit dijelaskan mengapa senyawasenyawa menyebabkan aroma yang berbeda, karena senyawa-senyawa yang mempunyai struktur kimia dan gugus fungsional yang hampir sama (stereoisomer) kadang- kadang mempunyai aroma yang sangat berbeda (Winarno, 1992).

\section{c. Warna}

Warna merupakan hal penting dalam menentukan kualitas dari suatu bahan pangan. Hal ini sesuai dengan pendapat (Winarno, 1992). Penentuan mutu bahan makanan pada umumnya sangat bergantung pada beberapa faktor diantaranya cita rasa, warna, tekstur, dan nilai gizinya. Tetapi sebelum faktor-faktor lain dipertimbangkan, secara visual faktor warna tampil lebih dahulu dan kadang- kadang sangat menentukan. Suatu bahan yang dinilai bergizi, enak, dan teksturnya sangat baik tidak akan dimakan apabila memiliki warna yang tidak sedap dipandang atau memberi kesan telah 
menyimpang dari warna seharusnya. Hasil Analisis Variansi (ANAVA) menunjukkan bahwa perlakuan perbandingan air rebusan bandeng presto dengan gula tidak memberikan pengaruh nyata terhadap warna saus ikan.

\section{Kesimpulan}

Berdasarkan hasil penelitian, dapat diambil kesimpulan yaitu perbandingan air rebusan ikan bandeng presto dengan gula aren berpengaruh terhadap karakteristik saus ikan, meliputi aroma, rasa, kadar gula total, kadar protein, kadar lemak, kadar air, kadar total padatan terlarut, dan viskositas. Tetapi tidak berpengaruh terhadap warna.

\section{Daftar Pustaka}

1. Ahmad, P. 2016. Penambahan Tepung Tapioka sebagai Bahan Pengental Terhadap Karakteristik Saus Pisang Moli. Universitas Andalas Padang.

2. AOAC. 2005. Official Methode of Analysis of The Associaton of Official Analytical Chemist, Association of Official Analytical Chemist, Washington D.C.

3. Astawan, M. 2004. Kandungan Gizi Aneka Makanan. Jakarta. Gramedia.

4. Badan Standardisasi Nasional. 1995. Standar Nasional Indonesia No. 01-0222-1995 Bahan Tambahan Makanan. Jakarta.

5. Badan Standardisasi Nasional. 2017. Standar Nasional Indonesia No. 4106: 2017. Bandeng Duri Lunak. Jakarta.

6. Badan Standarisasi Nasional.2004. Standar Nasional Indonesia 01-3546-2004. Saus Tomat.. Jakarta.

7. Bola Keluarga.2015. Hal Yang Penting Untuk Diketahui Tentang Tepung Tapioka. www.bolakeluarga. com.Diakses tanggal 08 Oktober 2019.

8. Buckle, K,.A R.,A., Edwards, G.H.Fleet, M,wootton, (2009). Ilmu Pangan. Penerjemah purnomo,H.,Adiono.Universitas Indonesia : Jakarta.

9. Cahyadi, W. 2008.Analisis Dan Aspek Kesehatan Bahan Tambahan Pangan. Bumi Aksara : Jakarta.

10. Citra, R, H. 2015. Formulasi dan Karakteristik Saus Berbahan Baku Hidrolisat Hasil Hidrolisis Enzimatik dari Ikan Inferior. Fakultas Teknologi Pertanian, universitas jember.

11. Deptan. 1992. Daftar Komposisi Bahan Makanan. Direktorat Gizi, Departemen kesehatan.

12. Dinas Kelautan dan Perikanan Kabupaten Pati. 2013. Daftar Pengolahan Ikan. kabupaten pati.

13. Eko, S. (2010). Bandeng Duri Lunak. http://bandeng_duri_l unak.pdf. Tanggal akses $1 / 11 / 2019$

14. Frida,G,P.2017. Pengaruh Konsentrasi Gula merah dan tapioca terhadap karakteristik dan sifat organoleptik petis air rebusan ikan bandeng. Universitas Pasundan. Bandung.
15. Gardjito, M. 2013. Bumbu Penyedap Dan Penyerta Masakan Indonesia. Gramedia Pustaka Utama. Jakarta

16. Gaspersz, V. 1995.Teknik Analisis Dalam Penelitian Percobaan. jilid I, Tarsito. Bandung.

17. Gisslen, W. 2007. Professional Baking. John Wiley \& Sons. Inc: Hobokken New Jersey.

18. Hadi, S. 2015. Ini Dia Manfaat Gula Aren Yang Perlu Kamu Ketahui.www.satujam.com. Diakses tanggal 10 oktober 2019

19. Hatta, S. 1993. Aren Budidaya dan Multiguna.Kanisius.Yogyakarta. Juwana, S. dan Romimohtarto. 2000.

20. Rajungan - Perikanan Cara Budidaya dan Menu Masakan. Djambatan, Jakarta.

21. Juwita, Wirda P, Rusmarilin, Herla, dan Yusraini, Era. 2014. Pengaruh Konsentrasi Pektin dan Karagenan Terhadap Mutu Permen Jelly Jahe.Universitas Sumatra Utara. Medan

22. Lempang, M. 2012. Pohon Aren dan Manfaat Produksinya. Balai Penelitian Kehutanan Makassar

23. Mirza. 2010. Karakteristik petis ikan dari limbahn cair hasil perebusan ikan tongkol. Departemen Teknologi Hasil Perairan Fakultas Perikanan dan Ilmu Kelautan Institut Pertanian Bogor.

24. Muchtadi, T.R., Sugiyono. 2010. Ilmu Pengetahuan Bahan Pangan. Universtas Pangan dan Gizi.IPB Bogor.

25. Nanang, D, S. Implementasi Teknologi Proses Dan Pengemasan Gula Aren Aneka Rasa Di UMKM Tanjung Siang Kab. Subang.

26. Nur, I. 2016. Karakteristi kimia, Fisika, dan Sensoris Saus Cuko Pempek. Universitas Muhammadiyah Palembang.

27. Nita, N. 2017. Pengaruh Perbandingan Stoberi Dengan Tomat Dan Penambahan Tapioka Terhadap Karakteristik Saus Stoberi. Universitas Pasundan. Bandung

28. Rosenfeld, T. 2011. Sear, Sauce, \& Serve: Mastering High Heat, High Flavor Cooking. United States: Running Press

29. Rumokoi, M.M.M. 1990. Manfaat tanaman aren (Arenga pinnata Merr). Balai Penelitian Kelapa, Manado. Buletin Balitka No. 10 Thn 1990 hal : 21

30. Sapari, A., 1994. Teknik Pembuatan Gula Aren. Karya Anda, Surabaya.

31. Sara, A, P. 2011. Pengaruh Konsentrasi Sukrosa Terhadap Kualitas Permen Jelly Daun Pepaya (carica papaya L.,). Universitas Atma Jaya Yogyakarta.

32. Sembiring,T.,Agustian,L.,Ariani, A. 2009. Peran Zinkum Terhadap Pertumbuhan Anak. Sari Pediatri 11, 244-249.

33. Sharoba.A.M, B. Senge and H.A. El- Mansy. 2005. Chemical, sensory and rheological properties of some commercial German and Egyptian tomato ketchups. Europe Food Technology Volume 220 No $142-151$ 